\title{
Effectiveness of Search and Rescue in Handling Victims in Water (Water Rescue): Case Study at the Kupang Class A Search and Rescue Office 2017-2019
}

\author{
Muhammad U. K. Niron ${ }^{1}$, Ajis S. A. Djaha ${ }^{2}$, Nursalam² \\ ${ }^{1}$ Master Program, Postgraduet School, Program Study Public Administration \\ University of Nusa Cendana, Kupang, Indonesia \\ ${ }^{2}$ Program Study Public Administration, University of Nusa Cendana, Kupang, Indonesia
}

Correspondence Author Email: muhammadelniron77@gmail.com

DOI: 10.29322/IJSRP.11.11.2021.p11953

http://dx.doi.org/10.29322/IJSRP.11.11.2021.p11953

\begin{abstract}
This study aims to describe and analyze the Effectiveness of the Implementation of Search and Rescue Operations in Handling Water Victims (Water Rescue), a Case Study in the A Class Kupang Search and Rescue Office 2017-2019.In identifying the objectives, this research uses a qualitative approach with the case study method. This method is considered in accordance with the purpose of research because it investigates and examines in a real-life phenomenon.Researchers become the main instrument in an effort to obtain and find data. Meanwhile, the research subjects consist of 15 people, including the Head of Kansar A Kupang Class, Head of Kasie Resources, Head of OPS and Standby, Search and Rescue Team, Members of Indonesian National Police, and Members of MENWA UNDANA Kupang. The data collection techniques used include observation, interviews and document study.Data analysis went through three steps of the flow model, namely reduction, presentation and verification of data. Bungin, (in Niron. Y. M. L, 2020: 171) said that the three steps happened simultaneously. The technique used to check the validity and the saturation of the data is the persistence and focus on observation and triangulation. The results of the study prove that the effectiveness of the implementation of search and rescue operations in handling victims in the waters (Water Rescue) Study at the Kupang Class A Search and Rescue Office in 2017-2019 is not effective in developing the implementation of search and rescue victims according to the Resource approach, Process approach and Goals approach.
\end{abstract}

Keywords: effectiveness, water resque, case study.

\section{INTRODUCTION}

East Nusa Tenggara, which is geographically located in the crossing route between Australia and the Asia Pacific and is on a direct border with a neighboring country, has the potential to cause shipping and aviation disasters, especially the mobility of the people of East Nusa Tenggara, is very dependent on sea and air transportation. Therefore, it is only natural that all components of the community in the East Nusa Tenggara region unite to continuously improve preparedness to anticipate disasters/disasters by forming an integral and integrated disaster management forum. In order for this to be achieved, a more proactive and dynamic role for the National Search and Rescue Agency and local governments is needed to gather all existing potentials into a reliable Search and Rescue force that is ready at any time of need. NTT is also an archipelago consisting of 1,192 islands where there are 4 large islands namely Flores Island, Sumba Island, Timor Island and Alor Island as well as other small islands that have the potential for accidents or disasters in the waters caused by the people of NTT mostly eyes. their livelihood as a fisherman and the means of transportation used are mostly sea transportation which are prone to accidents while carrying out their activities (Therik, Wilson). Based on data compiled from BASARNAS, the Kupang Class A Search and First Aid Office, it is stated that the greatest This publication is licensed under Creative Commons Attribution CC BY. 
potential for accidents in NTT is marine accidents. From 2017 to 2019 there were at least 110 cases of marine accidents, 1 case of air accident and 103 cases of natural disaster. must work hard to be able to carry out their duties and functions as an organization that is fully responsible for the operation of organizing rescue and search and handling of accident victims in the waters. In the initial observations, researchers found problems related to various resources used to carry out the duties and functions of the Kupang Class A Relief and Search Office related to the operation of organizing search and rescue as well as handling victims in the waters (water rescue), one of which is human resources, in addition to other problems. related to facilities/facilities are also still very limited. Until now, the operational facilities for conducting search and rescue of victims in the waters (water rescue) owned by the First Class A SAR Office Kupang only had 14 boat units (Ribber Boat and Rigit Inflatable Boat). With such conditions, the operation of organizing search and rescue of victims in the waters (water rescue).

The problem above is the basis of thought by researchers in conducting studies with the aim of describing and analyzing the Effectiveness of the Implementation of Search and Rescue in Handling Victims in Water (Water Rescue). The study at the Kupang Class A Search and Rescue Office in 2017-2019. The results of this study are expected to first contribute ideas about the basic concepts of organizational effectiveness related to the process of Effectiveness of Search and Rescue in Handling Victims in Water (Water Rescue). Second, contributing to Administrative Sciences to be used as a reference in studying and understanding Public Management, which in this case relates to the Effectiveness of Public Organizations. Thirdly, through this research, it is hoped that it can provide input to the Kupang Class A Relief and Search Office to evaluate the effectiveness of the Search and Rescue Implementation in the Handling of Victims in Water (Water Rescue) that has been carried out previously and can contribute conceptually and practically ideas for improving the implementation program. search and help in handling victims in the waters (Water Rescue) in the future. Fourth, as a reference for further researchers.

\section{METHOD}

This research uses a qualitative approach with a case study method. This approach was chosen because it is in accordance with the research objective which seeks to gain an understanding (verstehen) regarding the Effectiveness of the Implementation of Search and Rescue in Handling Victims in Water (Water Rescue). Study at the Kupang Class A Search and Rescue Office in 2017-2019. In the qualitative approach there are five research strategies, namely phenomenology, case studies, ethnography, grounded theory, and narrative (Creswell, 2010). The case study was assessed according to the purpose of this research, because it investigates and examines a symptom in a real-life setting. The location of the research in research on the Effectiveness of Search and Rescue from the Kupang Class A Search and Rescue Office in 2017-2019 in Handling Victims in Water (Water Rescue) is at the Class A Search and Rescue Office Kupang in 2017-2019 which is located at Adisucipto street, Penfui Village, Maulafa District, Kupang City. Research on the Effectiveness of Search and Rescue Implementation in Handling Victims in Water (Water Rescue). The study at the Kupang Class A Search and Rescue Office in 2017-2019 will be reviewed with three research focuses and developed into several research sub-focuses. Sources of data are, First primary data is data obtained directly from informants by conducting interviews and observations. The data can be in the form of opinions of subjects (people) individually or in groups, the results of observations of an object (physical). In this case, it is the result of an interview with the Kupang Class A Search and Rescue Office in 2017-2019. The two secondary data are sources of research data obtained by researchers indirectly through intermediary media (obtained and recorded by other parties). Secondary data is generally in the form of historical evidence, records or reports that have been compiled in published and unpublished archives. To answer the research questions posed, the resource persons/informants in this study were selected using purposive and sampling techniques. This technique is expected to help researchers to obtain informants in accordance with those proposed by Neuman (2013), namely a good informant must merge with the culture related to the event to be studied, 
must be directly involved with the researched, willing to take the time to provide information, and not the individual providing the analytical answer.

The data collection used in this study are First observation namely this data collection technique the researcher will review directly at the research location to obtain specific and empirical data based on the symptoms and phenomena of the implementation of search and rescue of victims in the waters (water rescue). Namely this data collection technique is carried out by conducting a question and answer process with the implementing party in this case the Class A Kupang Search and Help Office in 2017-2019 regarding the implementation of searching and helping victims in the waters (water rescue). Researchers will use conceptualized questions and other questions related to research problems and the focus of the study. The three Document studies are researchers in addition to conducting observations and interviews, researchers also study other data in the form of notes, archives, and other references in the form of newspapers, journals, articles and books that provide information on the effectiveness of the implementation of search and rescue of victims in the waters (water rescue) and supporting theories.

The data analysis method used in this study was qualitative data analysis obtained through in-depth interviews, and observations were made using the analytical method introduced by Miles and Huberman (in Sugiyono, 2013). Activities in data analysis are data condensation (data condensation), data display (data presentation), and conclusion drawing/verification (drawing conclusions). Bungin, (in Niron. Y.M. L, 2020: 171) said that the three stages took place simultaneously the data validity test in qualitative research according to Sugiyono (2012:121) includes the data credibility test, transferability test, depenability test, and confirmability test. In this study, credibility test was used to test the validity of the data. Test the credibility of the data is done by triangulation. Data triangulation is defined as checking data from various sources in various ways and at various times. There are 3 triangulations in the validity of the data, namely source triangulation, technical triangulation and time triangulation. In this study, researchers used source triangulation. Source triangulation is testing the credibility of the data by checking the data that has been obtained through several sources, namely observation data, interview data and documentation data.

\section{RESULTS AND DISCUSSION}

East Nusa Tenggara, which is geographically located in the crossing route between Australia and the Asia Pacific and is on a direct border with a neighboring country, has the potential to cause shipping and aviation disasters, especially the mobility of the people of East Nusa Tenggara, is very dependent on sea and air transportation. Therefore, it is only natural that all components of the community in the East Nusa Tenggara region unite to continuously improve preparedness to anticipate disasters/disasters by forming an integral and integrated disaster management forum. In order for this to be achieved, a more proactive and dynamic role for the National Search and Rescue Agency and local governments is needed to gather all existing potentials into a reliable Search and Rescue force that is ready at any time of need. NTT is also an archipelago consisting of 1,192 islands where there are 4 large islands namely Flores Island, Sumba Island, Timor Island and Alor Island as well as other small islands which have the potential for accidents or disasters in the waters caused by the majority of the people of NTT. livelihoods as fishermen and the means of transportation used are mostly sea transportation which are prone to accidents while carrying out their activities (Therik, Wilson). Based on data compiled from BASARNAS, the Kupang Class A Search and First Aid Office, it is stated that the greatest potential for accidents in NTT is marine accidents. From 2017 to 2019 there were at least 110 cases of sea accidents, 1 case of air accident and 103 cases of natural disasters. For more details can be seen in the following data: Table 3.1. Data on the Implementation of Rescue and Search for Victims in the Waters (water rescue) for 2017-2019

\begin{tabular}{|c|c|c|c|c|c|}
\hline Type of accident/year & Number of events & Number of victims & Safe & Die & Lost \\
\hline \multicolumn{6}{|l|}{ Ship } \\
\hline 2017 & 44 & 481 & 467 & 8 & \\
\hline 2018 & 57 & 346 & 360 & 17 & 9 \\
\hline
\end{tabular}

This publication is licensed under Creative Commons Attribution CC BY. 


\begin{tabular}{llccccc} 
& 2019 & 15 & 92 & 46 & 0 & 43 \\
\hline Aircraft & & & & & & \\
& 2017 & 2 & 46 & 0 & 0 & 0 \\
& 2018 & 0 & 0 & 0 & 0 & 0 \\
\hline Disaster & 2019 & 0 & 0 & 4 & 3 & 0 \\
& 2017 & 32 & 7 & 0 & 0 & 0 \\
& 2018 & 62 & 0 & 0 & 0 & \\
& 2019 & 7 & 0 & 0 & 0 & \\
\end{tabular}

Source: Kupang Class A SAR Office, 2020.

From the data in table 3.1. explained that cases of marine accidents in NTT have the greatest potential with the number of incidents in 2017 as many as 44 cases and causing 481 victims, in 2018 the number of cases was 57 cases and caused 346 victims, and in 2019 the number of cases was 12 cases and caused 92 victims. Meanwhile, if you look at the number of victims who died and went missing in cases of marine accidents from 2017 to 2019 it was still quite large. The number of victims who died due to marine accidents from 2017 to 2019 was 25 people, while the victims were missing and not found as many as 68 people. Effectiveness comes from the word effective which means a way of thinking, attitude and behavior as well as work results that have consequences, results or influences on something that is other. According to the Big Indonesian Dictionary, the word effective has the meaning of effect, influence, effect or can bring results. So effectiveness is the activity, usability, the existence of conformity in an activity of people carrying out tasks with the intended target. Effectiveness is basically, at the level of achievement of results, often or always associated with efficiency, although in fact there is a difference between the two, effectiveness emphasizes the results achieved while efficiency is more concerned with how to achieve the results achieved by comparing the input and output (Pasolang, 2007). 2007;124) followed by (Keban 2004:79), the notion of effectiveness is how well the work is done, the extent to which people produce outputs as expected. This means that a job can be completed with planning, both in time, cost and quality, so it can be said to be effective. Regarding the content of this thought (The Liang Giec in Pasolang 2007:215) citing the Encyclopedia of Administration conveys an understanding of effectiveness as follows: Effectiveness is a condition that contains an understanding of the occurrence of a desired effect or result, if someone performs an act with a specific purpose that is desired., then the person is said to be effective if it creates or has the intended purpose.

(Bevaola, 2014: 50) Implementation of Search and Help in Handling Victims in Water (Water Rescue) is a rescue or rescue activity as well as a way of moving victims from waters such as ponds, rivers, and the sea as well as other natural disasters. In the context of the effectiveness of Water Rescue Mathis 2006 states that the effectiveness of Water Rescue is the level of achievement of the results of natural disaster management activities with the set targets, simply a comparison of outputs with inputs. The higher the effectiveness ratio describes the more effective organizational capabilities.

The effectiveness of Kupang Class A Search and Rescue in the implementation of search and rescue operations in handling victims in the waters can also be said to be achieving maximum output with certain inputs or using the lowest input to achieve certain outputs, an output/input comparison associated with performance standards or targets. determined by the Kupang Class A search and rescue office.

To see the effectiveness of Class A Kupang Search and Rescue in the implementation of search and rescue operations in handling victims in the waters, the authors use the approach criteria understood to measure the effectiveness of an organization by Gibson 1989, namely the resource approach, namely measuring the effectiveness of the input. the process approach (process approach) and the target approach (goals approach) where the focus is on the outputs which will be discussed further through the discussion below: 
1. Input approach (resource approach) The input approach is all input or something that will be used by Kupang Class A Relief in carrying out search and rescue operations in handling victims so that they can run effectively, the sub focus that will be evaluated in this research is budget, facilities infrastructure and human resources.

a. Budget Resources

Budget or funds are a very important aspect in the implementation of search and rescue operations in handling victims, more precisely at the Kupang Class A Relief Office which is responsible for natural disaster management. The funds targeted by the government, which is under the responsibility of the Kupang Class A Relief Office, are the plans targeted by those concerned. The following are the targets and budget realizations set by KANSAR Class A Kupang for 2017-2019.

Table 3.2. Budget Target and Realization for Fiscal year 2017-2019 / Program

\begin{tabular}{clcccc}
\hline No & \multicolumn{1}{c}{ Program } & Pagu (Rp) & Realization (Rp) & \% \\
\hline 1 & $\begin{array}{l}\text { Management Support Program and Other Technical } \\
\text { Implementation }\end{array}$ & 569.717 .525 .000 & 546.409 .376 .536 & 95,91 \\
2 & $\begin{array}{l}\text { Apparatus Facilities and Infrastructure Improvement } \\
\text { Program }\end{array}$ & 160.018 .870 .000 & 147.798 .307 .965 & 92,36 \\
3 & Search Management Program,Rescue and Rescue & 1.505 .363 .165 .000 & 1.487 .130 .792 .557 & 98,79 \\
\hline & Total & $\mathbf{2 . 5 4 2 . 2 8 8 . 9 5 5 . 0 0 0}$ & $\mathbf{2 . 4 7 9 . 9 5 8 . 4 5 1 . 8 8 2}$ & $\mathbf{9 7 , 5 5}$ \\
\hline
\end{tabular}

Source: Kupang Class A SAR Office, 2017-2019.

Of the three programs, the Rescue Search and Rescue Management program is a program to achieve the strategic goals of the Kupang Class A Relief Office, namely the improvement of services in the implementation of SAR operations and the achievement of successful rescue of victims in the implementation of SAR operations. : Activities for the procurement of SAR facilities, both special SAR facilities, sea, land and air, SAR facilities maintenance activities, SAR deployment and control activities, SAR alert activities, SAR training activities. 2019 in the form of coordination meetings, workshops, socialization and so on.

\section{b. Infrastructure Resources}

Facilities and infrastructure are supporting activities for carrying out search and rescue operations in handling victims. The importance of the availability of facilities and infrastructure to support this activity is nothing but so that the Class A Kupang Relief Office can be facilitated to work and go to the field. Effectiveness related to Search and Rescue Operations in Handling Victims in (Water Rescue) Class A Kupang Search and Rescue Office 2017-2019 related to input in the search and rescue operation from the Kupang Class A Search and Rescue Office 2017-2019, in the form of limited human resources in addition to problems related to limited facilities and infrastructure. This can be seen in the following data:

Table 3.3. Operational Facilities for Searching and Helping Victims in Water (water rescue) in 2017-2019

\begin{tabular}{lcccl}
\hline \multicolumn{1}{c}{ Jenis sarana } & Target & Realisasi & Persentasi\% & \multicolumn{1}{c}{ Information } \\
\hline Ribber Boat & 5 & 1 unit & 20 & Good condition and used for training \\
Ribber inflatable boat & 10 & 13 unit & 65 & Good condition but only 1 unit used in training \\
Diving equipment & 20 & 15 set & 40 & Good condition but only 1 set used in training \\
Life jacet & 50 & 20 set & 40 & Good condition but used in training only 5 sets \\
\hline
\end{tabular}


Source: Kupang Class A SAR Office, 2017-2019.

The data in the table above shows that the facilities and infrastructure used in carrying out the search and rescue of victims in the waters (water rescue), from the last three years based on the target of ownership of infrastructure facilities and the realization of the last target is still very minimal or less with a percentage as shown in table 3.3. on. And as a result of observations of researchers related to infrastructure resources that are still inadequate. So that it can be seen in the picture below, which is the result of the researcher's documentation while in the field.

Figure 1. Infrastructure resources Class A search and rescue office Kupang year 2017-2019

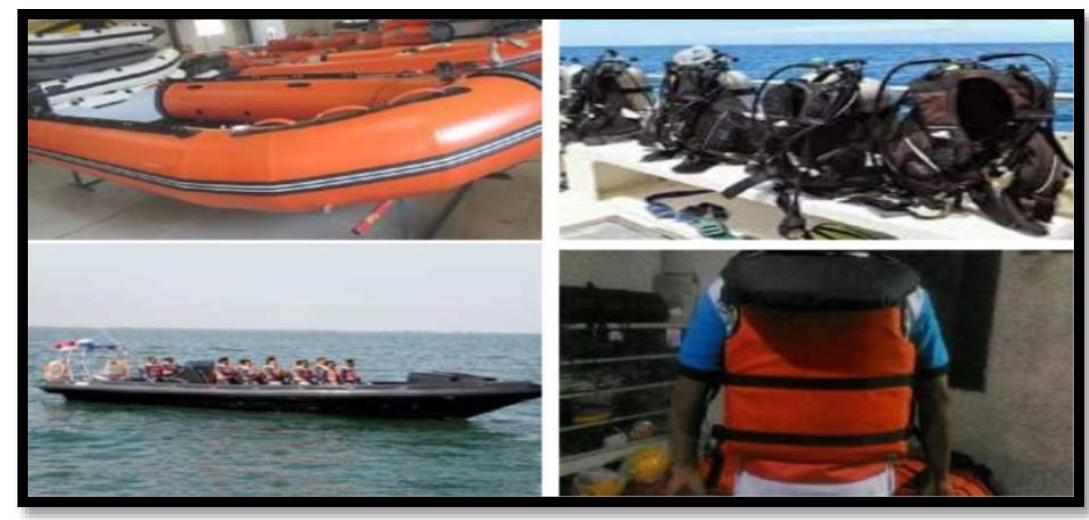

Source: Kupang Class A Search and Rescue Office Archives.

\section{c. Human Resources}

Human resources are a very important aspect in the implementation of tasks, activities, and daily activities. With quality human resources, the activities carried out will produce the desired output and run well. Human resources today are an aspect that also determines the success of a program or activity, not the case with human resources at the Kupang Class A Help and Search Office in conducting search and rescue of victims in the waters (water rescue). Adequate and quality human resources are needed. so that activities in conducting search and rescue of victims in the waters (water rescue) run well and have an impact on the desired output. The following are the human resources involved in activities to search and rescue victims in the waters (water rescue) at the Class A Search and Rescue Office Kupang.

Table 3.4. Human resources Class A Search and Rescue Office Kupang

\begin{tabular}{llccc}
\hline No & \multicolumn{1}{c}{ Officer } & Target & Realized & Percentage \% \\
\hline 1 & Administration staff & 20 & 14 & 70 \\
2 & The crew of the ship & 25 & 9 & 36 \\
3 & Radio operator & 8 & 3 & 37,5 \\
4 & Rescuer operators & 80 & 38 & 48 \\
\hline & Total & $\mathbf{1 3 3}$ & $\mathbf{6 4}$ & $\mathbf{4 8 , 1}$ \\
\hline
\end{tabular}

This publication is licensed under Creative Commons Attribution CC BY. 
Source: Kupang Class A SAR Office, 2017-2019.

From the document data above that the researcher obtained while conducting the research, it shows that the number of human resources at the Kupang Class A Relief and Search Office for the last three years has not been sufficient in carrying out the tasks and functions of search and rescue in the event of a disaster, especially human resources related to rescue workers who only work with rescue workers. totaling $48 \%$ of officers from the target resource set while for resources in general at the Kupang Class A Search and Rescue Office there are only $48 \%$ of the total human resources targeted to support search and rescue work for victims.

2. Process approach. The process approach considers effectiveness as the efficiency of conditions within the organization. This approach focuses on the extent to which processes that have occurred in the organization run smoothly, there is growing communication and attitudes in processing resources to produce cooled output. In relation to this research, the process approach in question is sure how the work process of the operation of organizing search and rescue of victims in the waters (water rescue) sub-focus that will be evaluated in this study relates to procedures and also coordination or collaboration between stakeholders.

\section{a. Search and Rescue Procedure}

Search and Help for disaster victims according to the Government Regulation of the Republic of Indonesia Number 22 of 2017 concerning Search and rescue operations, it is stated in Article 1 paragraph a that all efforts and activities are to search for, help, save, and evacuate people who face emergencies and/or dangers in accidents, disasters, or conditions that endanger humans. Search and rescue operations are also a series of activities including the implementation of search and rescue operations and the termination of search and rescue operations. safe place to receive adequate follow-up medical treatment. The problem found by researchers when conducting research is about procedures related to the operating time of the search and rescue operation which is relatively short. So that there are disaster victims who have not been found to date as follows:

Table 3.5. SOP for the Implementation of Search and Rescue in Handling Victims in Water (Water Rescue)

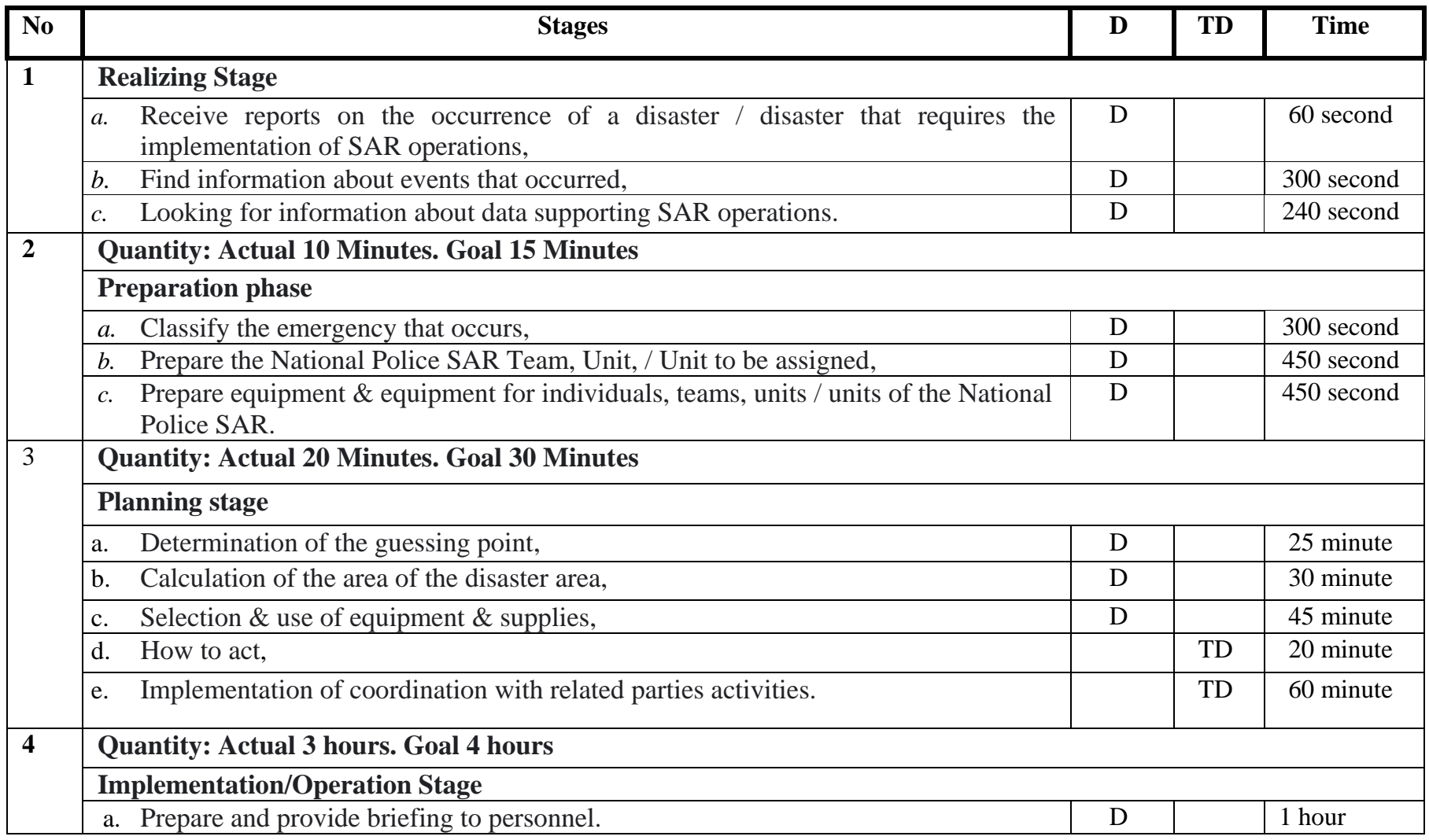

This publication is licensed under Creative Commons Attribution CC BY. 


\begin{tabular}{|c|c|c|c|}
\hline & $\begin{array}{l}\text { b. Finding the location of the victim, the next steps that need to be taken are; } \\
\text { Checking the latest condition of the victim, Stabilizing the condition of the victim } \\
\text { who is still alive, The victim dies with expert assistance, Evacuating the living and } \\
\text { dead victims, If there are large numbers of victims, a triage process is carried out } \\
\text { based on the level of gravity, with the aim of giving priority initial medical } \\
\text { treatment. }\end{array}$ & $\mathrm{D}$ & 4 hour \\
\hline \multirow[t]{7}{*}{5} & \multicolumn{3}{|l|}{ Quantity: Actual 5 hours. Goal 6 hours } \\
\hline & \multicolumn{3}{|l|}{ Final Stages of Task Implementation } \\
\hline & a. Withdraw personnel, equipment \& supplies from the field, & $\mathrm{D}$ & 2 hour \\
\hline & b. Field leaders carry out consolidation \& inspection of personnel conditions, & $\mathrm{D}$ & 3 hour \\
\hline & $\begin{array}{l}\text { c. Field leaders make a written final report \& report to the Unit as responsibility for } \\
\text { carrying out tasks, }\end{array}$ & $\mathrm{D}$ & 1 hour \\
\hline & $\begin{array}{l}\text { d. Conducting news (public inform) by SMC and Conducting anev on Giat Ops. SAR } \\
\text { has been carried out, }\end{array}$ & $\mathrm{D}$ & 2 hour \\
\hline & $\begin{array}{l}\text { e. The SMC returns the preparation of the National Police SAR equipment \& } \\
\text { equipment to the National Police agency, in the case that the National Police SAR } \\
\text { is on duty in a joint manner with Other SARs under the control of the SMC. }\end{array}$ & $\mathrm{D}$ & 2 hour \\
\hline
\end{tabular}

Source: Kupang Class A SAR Office, 2017-2019.

Based on the table above, it can be seen that the problems found by researchers when conducting research were about the procedures for carrying out operations for organizing search and assistance in handling victims (water resque), which was fairly short. However, almost all of the operational activities have fully complied with the SOP or in BASARNAS terms it is called the KPI (key performance indicator) which starts from the realization stage to the final stage of task implementation. There are several things that need to be improved in the implementation of the search and rescue operation as well as the handling of victims (water resque) are efforts to establish coordination at the planning stage of the operation.

\section{d. Coordination/Cooperation between Stakeholders}

Coordination is the systematic arrangement of various elements of management to ensure smooth functioning. Cooperation is described as the act of working together or conforming to standards, to achieve a common goal. In relation to coordination or cooperation between stakeholders in the search for help and handling victims (water resque) by the Kupang Class A Relief Office, there are problems related to the coordination that was built between the Kupang Class A Search and Rescue Office in 2017-2019. as illustrated in the SOP table in the implementation of the search for help and handling of victims (water resque) by the Kupang Class A Relief Office where the coordination factor for the stakeholder parties has not yet reached the target. Therefore, coordination should be carried out by 15 related agencies in the context of carrying out operations to search and rescue victims in the waters (water rescue), further details can be seen in table 4.6:

Table 3.6 Related Agencies/Institutions That Synergize in Operations Organizing Relief and Searching for Victims Handling in Water Rescue KANSAR Class A Kupang

\begin{tabular}{clc}
\hline NO & Name of Institution/Institution & Participants \\
\hline 1 & TNI & 16 participant \\
2 & POLRI & 4 participant \\
3 & Tagana Provinsi NTT dan Kabupaten & 4 participant \\
4 & TRC Provinsi NTT dan Kabupeten & 4 participant \\
5 & ORARI NTT & 2 participant \\
6 & Polisi Pamong Praja Prov. NTT & 2 participant \\
7 & Pemadam Kebakaran Kota (PMK) & 2 participant \\
8 & Palang Merah Indonesia Provinsi NTT dan Kota & 4 participant
\end{tabular}

This publication is licensed under Creative Commons Attribution CC BY. 


\begin{tabular}{clc}
9 & KKP & 2 participant \\
10 & Rumah Sakit & 2 participant \\
11 & Dinas Perhubungan & 2 participant \\
12 & Menwa Undana & 2 participant \\
13 & DINSOS & 6 participant \\
14 & ABK & 6 participant \\
15 & BPBD & 7 participant \\
\hline
\end{tabular}

Source: Kupang Class A SAR Office, 2020.

From the data above, it can be explained that in order to achieve effectiveness in providing aid and also searching for victims in the waters (water rescue), the Kupang Class A Rescue and Search Office for 2017-2019 coordinated and also synergized with other agencies/institutions. There are at least 15 agencies/institutions that participate in the Operation of the Implementation of Rescue and Search for Victims in the Waters (Water Rescue). However, problems in the coordination built between the Kupang Class A Search and Rescue Office in 2017-2019 as well as seeing from the experience of handling cases of search and rescue operations that have been carried out before, it turns out that coordination has not been well established which has resulted in not all of the agencies listed above being involved. This of course will be a problem in achieving the effectiveness of a performance.

3. Output Approach. The output approach is a measurement of effectiveness that focuses on aspects of the planned output or results, in the words of the target approach, measuring the effectiveness of the extent to which the organization succeeds in the goals to be achieved. In relation to this research, the intended output is the result of the input and implementation of search and rescue. The expected output is "Achieving the success of rescuing victims in the implementation of search and rescue operations" supported by the Main Performance Indicators (IKU) "Successful evacuation of victims in search and rescue operations." and found in the implementation of search and rescue operations. For the percentage of the number of victims saved in the implementation of search and rescue operations, it is measured by the number of survivors and victims found in good health, minor injuries and serious injuries from the total number of accident victims recorded during the emergency response implementation.

The following is a comparison of the percentage of the number of survivors and those found (including survivors and those who died where they were found) for the 2017-2019 period.

Table 3.7 Comparison of the Percentage of Survivors in 2017-2019.

\begin{tabular}{cccc}
\hline Year & Total of Victims & Victims Congratulations & Percentage \% \\
\hline 2017 & 30 & 25 & 83.3 \\
2018 & 50 & 31 & 62 \\
2019 & 20 & 3 & 15 \\
\hline
\end{tabular}

Source: Kupang Class A SAR Office, 2020.

As for the comparison of the number of victims found by the 2017-2019 period, it can be seen in the following table.

Table 3.8 Comparison of the Percentage of the Number of Victims Found

\begin{tabular}{cccc}
\hline Year & Total Number of Victims & $\begin{array}{c}\text { Number of Victims Found } \\
\text { (Survived + Died) }\end{array}$ & Percentage\% \\
\hline 2017 & 30 & 26 & 86.7 \\
2018 & 50 & 46 & 92 \\
2019 & 20 & 18 & 90 \\
\hline
\end{tabular}

Source: Kupang Class A SAR Office, 2020.

This publication is licensed under Creative Commons Attribution CC BY. 
As for the comparison of the number of victims who disappeared for the 2017-2019 period, it can be seen in the following table.

Table 3.9 Comparison of the Percentage of Number of Victims Not found

\begin{tabular}{cccc}
\hline Year & $\begin{array}{c}\text { Total Number of } \\
\text { Victims }\end{array}$ & $\begin{array}{c}\text { Number of Victims Found } \\
\text { (Survived + Died) }\end{array}$ & $\begin{array}{c}\text { Number of Victims } \\
\text { Not Found }\end{array}$ \\
\hline 2017 & 30 & 26 & 4 \\
2018 & 50 & 46 & 4 \\
2019 & 20 & 18 & 2 \\
\hline
\end{tabular}

Source: Kupang Class A SAR Office, 2020.

From the results of the analysis of the three tables, it can be seen that for the evacuation of victims in the SAR operation in 2019 the number of victims found was 18 people or $90 \%$, while the victims who were saved were 3 people or $15 \%$. When compared from the previous year, the percentage of survivors was found to have fluctuated increases and decreases. This is because the inputs and processes described above serve as notes for the Kupang Class A Search and Rescue Office to correct existing deficiencies, both in terms of human resources, infrastructure, search procedures, stakeholder collaboration. A Kupang can be achieved. It is an important note that in the last three years there have been 10 disaster victims who were not found by the Kupang Class A Search and Rescue Office. With shortcomings such as facilities and infrastructure, coordination that is not optimal and the procedure for finding victims that must be improved, the Class A SAR office in Kupang always strives to maintain and add facilities to support the smooth implementation of SAR operations and increase cooperation with existing stakeholders.

\section{CONCLUSION}

Based on the results of the research and discussion described in the previous chapter, the conclusion is that the effectiveness of the implementation of search and rescue operations in handling victims in the water (water rescue) ultimately has an ineffective effectiveness value, this is due to the achievement of the final results from the Class A Search and Rescue Office. Kupang, namely the evacuation of victims in search and rescue operations has not gone well, it can be seen that from 2017-2019 there were 10 victims who had not yet been found. The basis of the analysis used is using the effectiveness model of Gibson (1989) which is seen from 3 approaches namely input, process, and output, namely:

1. Resource approach where input or something that will be used by the Class A Search and Rescue Office such as the budget that is always available, infrastructure is not optimal, making it difficult for the team to carry out their duties and work, and human resources are not adequate with the workload, making it difficult for the team when searching and victim assistance.

2. The approach process/process in which the search and rescue procedures carried out by the Kupang Class A Search and Rescue Office were ineffective because in a short time the search was immediately stopped taking into account time, infrastructure/disaster areas and many more. So from that for the last 3 years as many as 10 victims have not been found if seen from this fact this is not in accordance with the mandate Number 22 of 2017 concerning search and rescue operations; And for coordination/cooperation with stakeholders by the Kupang Class A Search and Rescue Office which is ineffective because when a disaster occurs for the victim search process, the Kupang Class A Search and Rescue Office Team does not want to involve stakeholders with the argument that it will interfere with the search and rescue process.

3. Goals approach/Output where the evacuation of victims in search and rescue operations is achieved every year, but for the last 3 years from 2017-219 there were 10 disaster victims who were not found by the Kupang Class A Search and Rescue Office. With shortcomings such as facilities and infrastructure, coordination that is not 
optimal and the procedure for finding victims that must be improved, the Class A SAR office in Kupang always strives to maintain and add facilities to support the smooth implementation of SAR operations and increase cooperation with existing stakeholders. it can be concluded that the effectiveness of the implementation of search and rescue operations in handling victims in the waters (Water Rescue). The study at the Kupang Class A Search and Rescue Office in 2017-2019 was not effective in developing the implementation of search and rescue for victims.

\section{REFERENCES}

A. Anwar Prabu Mangkunegara, 2013, Manajemen Sumber Daya Manusia Perusahaan, Remaja Rosdakarya, Bandung.

Agung, Kurniawan 2005. Transformasi Pelayanan Publik. Yogyakarta: Pembaharuan.

Creswell, J.W. (2010). Research design: pendekatan kualitatif, kuantitatif, dan mixed.Yogjakarta: PT Pustaka Pelajar.

Edy Sutrisno, 2014. Manajemen Sumber Daya Manusia. Cetak Ke Enam. Pranada Media Group, Jakarta.

Georgopolous dan Tannen baum. 1985. Efektivitas Organisasi. Jakarta: Erlangga

Handayaningrat, Soewarno. 1994. Pengantar Studi Ilmu Administrasi dan Manajemen. Jakarta: Haji Masagung.

Hasibuan, Malayu S.P, 2013. Manajemen Sumber Daya Manusia. Edisi Revisi, PT.Bumi Aksara Jakarta.

Georgopolous dan Tannen baum. 1985. Efektivitas Organisasi. Jakarta: Erlangga

Gie,The Liang .1998. Ensiklopedia Administrasi. Jakarta: Gunung Agung.

Bevaola Kusumasari, 2014, Manajemen bencana dan kapabilitas Pemerintah Lokal,Yogyakarta : Penerbit Gava Media.

Hidayat. 1986. Teori Efektivitas Dalam Kinerja Karyawan . Gajah Mada University Press. Yogyakarta.

Indrajid, T.R. (2013). Faktor-faktor yang mempengaruhi Efektivitas Organisasi pada Kantor Kecamatan Tanjung pinang Barat. Naskah Publikasi, Jurusan Ilmu Administrasi Negara Fakultas Ilmu Sosial dan Politik Universitas Maritim Raja Ali Haji Tanjung pinang.

Irawati, N. (2013). Hubungan Kualitas Pegawai dengan Efektivitas Organisasi di Biro Humas dan Protokol Sekertariat Dearah Provinsi Kepulauan Riau. Naskah Publikasi, Jurusan Ilmu Administrasi Negara Fakultas Ilmu Sosial dan Politik Universitas Maritim Raja Ali Haji Tanjung pinang.

Mathis, R.L. \& J.H. Jackson. 2006. Human Resource Management: ManajemenSumber Daya Manusia. Terjemahan Dian Angelia. Jakarta: Salemba Empat.

Miles,M.B, Huberman, A. M, dan Saldana,J. 2014.Qualitative Data Analysis, A Methods Sourcebook, Edition 3. USA: Sage Publications. Terjemahan Tjetjep Rohindi Rohidi, UI-Press.

Neuman, W. Lawrence. 2013. Metode Penelitian Sosial: Pendekatan Kualitatif danKuantitatif. Edisi Ketujuh. Jakarta: PT Indeks

This publication is licensed under Creative Commons Attribution CC BY.

http://dx.doi.org/10.29322/IJSRP.11.11.2021.p11953

wWw.ijsrp.org 
Pasolong, Harbani, 2007,Teori Administrasi Publik, Alfabeta, Bandung.

Purnomo, Andri Joko,2006, “ Analisis Efektivitas Organisasi Dinas Perikanan dan Kelautan Kabupaten Batang”,Tesis, Semarang: Program PascasarjanaUniversitas Diponegoro.

Prasetya Irawan, 2006. Penelitian Kualitatif \& Kuantitatif untuk Ilmu-Ilmu Sosial, Jakarta: Departemen Ilmu Administrasi FISIP-UI.

Rofai, A. (2006). Analisis Faktor-Faktor Yang Mempengaruhi Efektivitas Organisasi Pada Badan Kesatuan Bangsa Dan Perlindungan Masyarakat Propinsi Jawa Tengah. (Tesis). Universitas Diponegoro, Semarang.

Sugiyono. 2012. Metode Penelitian Kuantitatif Kualitatif dan R\&D. Bandung: Alfabeta. 